\title{
Arab Nationalism in the Twentieth Century
}

Adeed Dawisha

Princeton, NJ: Princeton University Press, 2002. 352 pages.

In Arab Nationalism in the Twentieth Century, aptly subtitled From Triumph to Despair, Adeed Dawisha provides us a most compelling narrative. $\mathrm{He}$ 
tells of a time, not long ago, when Arabs still believed that a glorious future was ahead of them. Today, the very thought of a fiery, charismatic Arab leader, adored by his people and rising to oppose the West, seems silly and unrealistic. But four decades ago, Egyptian President Gamal Abd al-Nasser was hailed as nothing less than a modern-day savior, and it seemed - if only for an instant - that the unification of the Arab world was not just probable, but a historical inevitability. Dawisha goes beyond the successes, excesses, and outright failures that defined Arab nationalism at its height. Using a wide variety of English and Arabic source material, he weaves a complicated picture, analyzing in detail how Arab nationalism was born and how it would die just as quickly.

Central to his argument is that, from the beginning, Arab nationalism faced an uphill battle in its bid to win over an otherwise indifferent (and illiterate) populace. The author takes particular issue with George Antonious' thesis that leading up to World War I, the region's elites and masses had been stirred by "the Arab will to freedom." It would prove terribly difficult for the nationalists to compete with entrenched pan-Islamic identities. For this reason, the most prominent early advocates of the nationalist ideal were Christian, such as the Syrians Negib Azoury and Ibrahim al-Yajizi. The Muslim elites were suspicious, seeing in Arab nationalism, with its secular emphasis, a perfidious plot to divide them.

Dawisha rightfully devotes an entire chapter to the person and ideas of Sati al-Husri, the godfather of Arab nationalism and its chief ideologue and propagandist. Throughout the 1920s, in Syria and then in Iraq, al-Husri, as minister of education, had the opportunity to put his ideas into practice. In his forceful - almost messianic - vision, we are offered a glimpse into the bleak authoritarian future that would characterize the Arab world for the better part of the twentieth century. For al-Husri, any talk of democracy and individual liberty was seen as an irrelevant distraction from the task at hand - building the Arab nation.

The author emphasizes repeatedly that through the 1940s, Arab nationalism was in the minority, lagging far behind more well-established ideologies. In Egypt, wataniyah was in vogue among the intelligentsia, while Islamism was unrivaled among the masses, with an estimated 1 million members in the Muslim Brotherhood. Only the Palestinian revolt of 193639 , coupled with mounting fears of Jewish immigration, decisively altered the equation. Governments faced immense popular pressure to support the Palestinian cause, which, in turn, forced them to cooperate and speak with a unified voice in the international arena. 
For many readers, the author's discussion of Nasser's nationalist credentials will likely be the most surprising part of the book. At first, as Dawisha explains in detail, Nasser showed little interest in Arab nationalism. As late as 1954, the high school curriculum developed by the revolutionary regime contained few references to Arab nationalism. Moreover, in negotiating the text of Egypt's 1956 constitution, only at the urging of Riad Taha, a Lebanese journalist and close friend of Nasser, was a reference to Egypt as "part of the Arab nation" included.

At this early stage, Nasser saw Arab nationalism as a convenient tool with which to further Egypt's greater strategic objectives. Only by appealing to regional Arab sentiment could he effectively counter the West's imperialist ventures. As the United States and Britain reached out to Arab countries in hopes of forming a security alliance, Nasser's fear of isolation heightened. He reacted accordingly, using the language of Arab unity to rally the Arab masses in the face of an encroaching West.

Beginning in 1955, the Baghdad Pact, the infamous Czech arms deal, followed by Nasser's nationalization of the Suez Canal the next year would prove the decisive events in Arab nationalism's staggering ascendancy. Nasser had been vindicated, but events took a life of their own, and Nasser was hard-pressed to control the forces he had unleashed. Dawisha paints the portrait of a man torn between practical realities and the irresistible allure of the Arab dream. Despite his better judgment, Nasser had no choice but to live up to his promises of Arab unity, culminating in his reluctant acceptance of a union with Syria in which he did not really believe. Yet at the time, the march toward unity seemed unstoppable and, here, Dawisha deftly captures that rare moment in Arab history, when millions of jubilant Arabs waited to be carried toward the promised land of total Arab unification under the stewardship of their fearless leader. From that point on, with the breakup of the United Arab Republic, Egypt's continuing rifts with revolutionary Iraq, and then Nasser's misadventure in Yemen, things slowly came apart. Despite these setbacks, however, Arab nationalism remained ideologically dominant until the 1967 war with Israel.

Dawisha describes the hysteria that engulfed the Arabs on the eve of war. He recounts one amusing instance when Iraqi president Abdel Rahman Aref told his forces to behave properly in the "forthcoming occupation of Israel." Yet, in Abd al-Nasser, we see something different, a man who was much less optimistic about Arab victory. Keenly aware of its military prowess, he sent numerous signals to Israel, making clear his preference for a peaceful alternative. But, once again, Nasser was carried by events over 
which he himself had little control. The rest is history. The Arabs were left to dream what might have been and what will surely never be.

The author's lengthy postmortem of Arab nationalism, or autopsy, if you will, is a fascinating indictment of authoritarianism. He faults Arab nationalism's acute inability to survive setbacks on "the disinterest of its custodians in creating workable democratic institutions" (p. 297). For too long, Arab nationalism had been a one-man show. The idea of Arab nationalism was built on the charisma and vision of an authoritarian leader, and when that leader fell, the idea was doomed to die with him.

In the end, Arab nationalism succeeded in renewing a sense of dignity and self-worth. Yet, even with two decades of the nationalist project infused into the Middle East, the pervasive authoritarianism remains with us to this day. Central to the nationalist ethos was that in the singular pursuit of unity, there was no room for democratic dissent. Many Arabs seemed to agree, their hatred of imperialism translating into a distrust of "western" democratic institutions. We are told of Iraqi demonstrators in 1958 chanting " $\mathrm{Al}$ qawmiyah al- 'Arabiyah tufni al-Ahzab al-Gharbiyah" (Arab nationalism eliminates Western political parties" (p. 305). This, of course, leads us to an interesting question, particularly relevant today: Will increasing antiwestern sentiment in the Arab world translate into increasing doubt about the desirability of "freedom" and "democracy"? This has not yet happened. But if history is any guide, perhaps it soon will.

Dawisha's final observation is his most provocative: Had it not been for the western presence in the Arab world, nationalist revolution would have swept the region with little resistance. For example, it is hard to imagine how Lebanon and Jordan would have survived Nasser's ideological and political onslaught without western intervention on their behalf. Unlike in eighteenth- and nineteenth-century Europe, "no Arab state was allowed to accumulate power and territory and by so doing create the possibility for one unified Arab state, the ultimate goal of Arab nationalism."

Whatever one's ideological inclinations, the story that Dawisha tells is an affecting one. As far as modern Arab history is concerned, this - the demise of Arab nationalism - will stand as one of the great tragedies to befall the human spirit. Even for someone such as this author, who disagrees with the basic premise of Arab nationalism, reading this superb piece of scholarship rekindled a fire in me, forcing me to ask that most troubling of questions: What if ...? 